Article

\title{
The Effect of Innovation Capability on Business Performance: A Focus on IT and Business Service Companies
}

\author{
Seung Hoo Jin ${ }^{1}$ and Sang Ok Choi ${ }^{2, *}$ \\ 1 Science and Technology Studies, Korea University, Seoul 02841, Korea; jjamesjin@korea.ac.kr \\ 2 Department of Public Administration, Korea University, Seoul 02841, Korea \\ * Correspondence: sangchoi@korea.ac.kr; Tel.: +82-10-4219-7119
}

Received: 24 August 2019; Accepted: 21 September 2019; Published: 25 September 2019

check for updates

\begin{abstract}
With the introduction of a wide variety of new technologies during the fourth industrial revolution, companies in Korea have attempted to enhance their innovation activities, which include investment in new technology adoption, technical and non-technical innovation factors, and Research \& Development (R\&D) activity, to ensure the development and growth of their business performance and sustainability. In particular, IT and business services, two important industries in Korea, have been impacted by the development of new technology and have sought to adopt new technologies as soon as possible to survive in a rapidly changing business environment. The aim of our study is to empirically explore the effect of innovation activities on the performance of Korean IT and business service companies. To achieve this aim, we examine the innovation activities and business performance of 160 companies (80 large companies and 80 small- and medium-sized enterprises (SMEs)) in the IT and business service industries in Korea from 2009 to 2017. This study empirically analyzes panel data using fixed effect and random effect models with Hausman tests. According to our results, an improvement in product innovation has a positive impact on business performance (i.e., revenue and labor productivity) in both large companies and SMEs, as does R\&D investment, research resources, and company age. However, an improvement in process innovation only has a positive impact on the business performance of large companies, and R\&D cooperation only has a positive impact on the business performance of SMEs. As a result, both large companies and SMEs should concentrate on technological innovations to improve their sustainability and thus ensure their success in the long term.
\end{abstract}

Keywords: technology innovation; business performance; panel analysis

\section{Introduction}

Since Schumpter [1] referred to technological innovation as a key factor in corporate performance, numerous studies have been conducted on this topic. Previous research on technological innovation can be divided into case studies and statistics-based studies. Case studies typically investigate leading global companies such as IBM, Intel, and P\&G and analyze innovative cases from the perspective of users [2-5]. Previous studies have also statistically demonstrated the impact of technological innovation activities on corporate performance [6,7]. Previous research has reported that domestic and foreign companies use technological innovation activity as a corporate strategy to survive and increase their competitiveness [8]. It has also been shown that technological innovation activity has a positive impact on corporate performance [9]. For example, in terms of product innovation, entering a market with new or re-engineered products is a very important decision-making factor [10]. In addition, companies both large and small gain their own benefits and sustainable development in all of its 
aspects, social, environmental, and economic, in terms of technological innovation; green technology. There are a lot of ways technological innovation can play a role in environmental, economic, and social sustainability to introduce technological advances in health, business, and environment to create new jobs and opportunities [11]. However, despite a number of studies showing that technological innovation activity has a positive effect on corporate performance, some statistical research has reported that this activity may not necessarily have a positive effect, depending on the characteristics of the company or when they enter the market [12]. One study has reported that it could not find a strong link between corporate technological innovation and increased sales [13], while other research has emphasized that innovation is the most important component of corporate growth and that investment in technological innovation is the most common strategy to increase growth [14]. The reason for these conflicting results is that the types and characteristics of technological innovation in companies are fairly complicated, and there have also been differences in the statistical and analytical methods adopted by researchers [12]. Despite the fact that the importance of innovation has gained considerable support from a mix of economic theory, empirical research, and practical business experience, there has been a mixed argument in the results of the empirical analysis. Our research focuses on the effect of technological innovation activities on corporate performance depending on the size of the company, although there are various strategies for corporate performance. Our study analyzes how technological innovation activities affect business performance in the IT and business service industry, which has played an important role in Korea's industrial development, and compares the outcomes for large and small businesses. Based on the research results, this study offers academic and practical contributions in providing a basis for deciding which technological innovation strategy should be pursued that best suits the size of the company. The research model and hypotheses are established based on the theoretical background and previous research on technological innovation and corporate performance. The technological innovation activity and financial information for 80 large companies and 80 smalland medium-sized enterprises (SMEs) in the Korean IT service industry from 2009-2017 from the Science and Technology Policy Institute (STEPI) and the Financial Supervisory Service of Korea were then analyzed.

\section{Literature Review and Research Framework}

\subsection{Technlogical Innovation}

Technological innovation refers to the introduction of new technologies related to products, services, and processes to reduce production costs by creating a new combination of inputs, thus leading to improvements in existing products or new products or services [15]. These technological innovations increase the value-added for a company, and applying new technological changes to products and manufacturing processes typically results in considerable organizational change [16]. Technological innovation is the process of creating and commercializing new ideas, which means the production process for products and services that are the core of organizational technology [17]. In addition, in the process of actively responding to the market and developing new technologies, technological innovation will succeed in terms of the sustainable management of organizations [18]. Technological innovation is therefore a major driving force for improving the competitiveness of an organization and the productivity of the industry as a whole, leading to the economic development of the entire country and a more innovative society [19]. Therefore, it is necessary to have the capability to systematically manage this process to ensure successful innovation [19]. Technological innovation was originally defined as a series of phenomena that lead to the production and sale of new products or services through a novel combination of the production process, the market, materials, and organization [12]. Since then, the meaning and interpretation of innovation have changed incrementally. Product innovation is the ability to regularly deliver new products to the market and to add new features to existing products, involving a combination of technologies to satisfy consumers or the market. In contrast, process innovation reduces production costs by developing new technologies to 
dramatically improve the productivity and/or innovation of process technology that operates between the input and output [12].

Product innovation and process innovation are not independent of each other. After a product is standardized following product innovation, process innovation occurs, and the company can respond strategically to a rapidly changing environment by repeating this process. In particular, this continuous cycle of innovation activity represents the evolutionary process of successful companies [10]. Technological innovation has also been defined as the flow of information used to develop and implement ideas and the activities within the business process as a whole, from the technology of the products and processes to the management systems [11]. Research on innovation and corporate performance has revealed that product innovation provides a competitive advantage to companies through technological superiority and improved product performance, while process innovation provides a competitive advantage in terms of greater productivity and efficiency [12].

The technological innovation of a company is recognized as a key factor in securing its competitiveness and improving its performance [20]. On the other hand, there are structural differences in the process and results of innovation depending on the research and development (R\&D) activities that are conducted and on the unique innovation strengths, weaknesses, opportunities, and threats that exist according to the size of the company. Because the size of the knowledge base and the learning opportunities differ by industry and company size, there may also be a difference in the process of developing innovation strategies [21].

\subsection{Technological Innovation and Business Performance}

In the early days of the Industrial Revolution, serious social conflict arose in the short term when workers were replaced by technological innovations. However, because technological innovation generated more demand and consequently increased production, it created more employment and added value to the economy. As a result, the dominant academic and policy view is that technological innovation can present marginalized workers with new employment opportunities as a form of compensation within the market [20]. Therefore, analyzing the results of innovation in terms of both financial and social performance will not only emphasize the importance of innovation but also provide an important foundation for the structural theory that technological innovation contributes to corporate growth and competitiveness [22]. In the turbulent business world, technological innovation has become a main focus of top management levels in various companies [10]. It is argued that those firms can succeed by implementing modern technology to their products and services [23]. From a strategic management perspective, particularly from a resource-based view, a firm with unique capabilities and resources can attain a sustainable competitive stand in a turbulent business market and outperform its industry competitors [21]. Technological innovation can help companies to develop a variety of new products and services that are important factors for high performance and profits [24]. In a turbulent market, those firms which have high technological capabilities become leaders of the market and gain high profitability [25]. Particularly, in emerging markets, a firm's goal for high profit and survival can be achieved through technological innovation [26]. Technological innovation is not only practicable in a specific industry [27] but various industrial sectors, such as manufacturing and services, improve their performance by adopting technological innovation [28]. Technological innovation is regarded as an important driver factor that significantly contributes to business performance [29]. The importance of a firm's technological innovation capability, which can be beneficial to the company and leads to improved competitiveness, has been confirmed by many studies [10]. It was proven that Industry 4.0 is key to the improvement of sustainable business performance for SMEs. Elements of Industry 4.0 have a positive effect on promoting information technology (IT) implementation, which helps the sustainable business performance of the firms because it will not only lead to changes in the service production on SMEs but big reforms can also be seen in other areas, such as business models and labor markets [30,31]. It was also found that there is a relationship between Industry 4.0 and the size of the firm. Large firms are better prepared for Industry 4.0 than small and medium firms, as they have 
many more resources to utilize to implement Industry 4.0, technological innovation [32]. The essential reason for adapting Industry 4.0 into real business practice is to strength business competitiveness [33]. Industry 4.0 is no longer an agenda to be discussed by large enterprises only. On the other hand, it is necessary for SMEs to fulfil the factors of Industry 4.0 to be able to produce their products and services more efficiently $[32,33]$.

However, different researchers argued different capabilities as major determinants of firm's innovation performance. Teece pinpointed that innovation is an interactive process between technologically-related sub-systems [34]. Evangelista et al. considered R\&D activities as the most important intangible expenditure for innovation [35]. Danneels suggested the importance of customer competence and technological competence on product innovation [36]. Galende and Fuente emphasized the impact of organizational resources, commercial resources, and internationalization on innovation [37]. An extensive and comprehensive study on the relationship between the determinants of innovation and a firm's innovation performance still requires further study. This makes it difficult for companies to perform actions in improving their technological innovation competitiveness and the business performance [12].

\section{Research Framework and Hypothesis}

\subsection{Product Innovation and Performance}

Technological innovation increases competitiveness by improving product quality and manufacturing capacity. Consumer satisfaction then increases as the quality level of the product meets user expectations, and sales rise due to increased demand. Thus, this process can be the driving force for improvement in business performance [38]. In other words, companies can gain a competitive edge in their industry and raise profits, the ultimate goal of most companies, through technological innovation activities. This competitive advantage can help to expand their market share, improve sales, and ultimately contribute to improving corporate performance [39]. As a result, product innovation has a positive effect on the performance of an organization, with $R \& D$ for new products, the innovative improvement of the quality of products, and the intention to continuously release innovative products on the market allow it to gain a competitive advantage [40]. In other words, the ability to continuously develop valuable products is difficult for competitors to replicate and cannot be easily replaced, which can lead to a competitive advantage over time. This competitive advantage allows the market and customers to recognize the technical advantages of the products, thereby increasing the market share and increasing profitability for the company [41]. Therefore, it can be assumed that product innovation can have a positive effect on an organization's performance by creating new systems related to product development and an improvement in quality and innovation.

Hypothesis 1. Technological innovation activities for product innovation in SMEs will improve the performance of the company.

(1) Technological innovation activities for product innovation in small and medium companies will improve the revenue performance of the company;

(2) Technological innovation activities for product innovation in small and medium companies will improve the labor productivity performance of the company;

(3) Technological innovation activities for product innovation in large companies will improve the revenue performance of the company;

(4) Technological innovation activities for product innovation in large companies will improve the labor productivity performance of the company. 


\subsection{Process Innovation and Performance}

In the fluid phase of a new market, where there are no set specifications or designs for products, product innovation is more active than process innovation, and a dominant design can emerge from a number of design options [42]. Until the emergence of a dominant design, product innovation activities that aim to reflect market and customer requirements are prevalent [43]. However, no matter how good a design is, it will not be able to fully meet the needs of the market and its customers if it does not overcome the limitations of existing process technologies. Therefore, companies switch their focus to process innovation during this transition stage. This improves the manufacturing capability by overcoming existing technical limitations [40], after which companies are able to improve production efficiency, such as by reducing production costs, and improve the technical specifications of their products [44]. As a result, corporate performance will rise due to the improvement in market competitiveness and the availability of higher-quality products, which users want [45].

Hypothesis 2. Technological innovation activities for process innovation will improve the performance of the company.

(1) Technological innovation activities for process innovation in small and medium companies will improve the revenue performance of the company;

(2) Technological innovation activities for process innovation in small and medium companies will improve the labor productivity performance of the company;

(3) Technological innovation activities for process innovation in large companies will improve the revenue performance of the company;

(4) Technological innovation activities for process innovation in large companies will improve the labor productivity performance of the company.

\subsection{RED Cooperation and Performance}

Previous research has shown that cooperation is an effective way to improve corporate technological innovation [46]. Therefore, cooperation with external organizations has been recognized as an important strategy in replenishing an organization's internal innovation capabilities [47]. Companies are increasingly pursuing cooperative relationships with a range of external partners, such as academic research institutes and other companies, to create sustainable growth [48]. However, it is difficult to firmly conclude that external R\&D cooperation is always beneficial to corporate innovation performance because the strategies of large companies and SMEs may differ [49]. For example, large companies are likely to be wary of R\&D cooperation with outside companies because of the "free-ride effect", which can be used as an advantage for large companies and SMEs. In addition, research related to new product development shows that if a company lacks absorption ability, cooperation with outside organizations can act as a hindrance to innovation [50]. Unlike large companies, however, SMEs are expected to benefit from cooperating with external organizations for the purpose of knowledge acquisition through technical alliances, the development of leading companies, and the imitation of fair-use technology [51]. Therefore, SMEs are expected to conduct more active R\&D activities with outside companies, while large companies will be more careful in pursuing cooperative R\&D activities if their internal technology has a leading position in the market [51]. Research model was defined from the hypotheses (Figure 1).

Hypothesis 3. RED cooperation with outside companies will improve the performance of companies.

(1) R\&D cooperation with outside companies in small and medium companies will improve the revenue performance of the company;

(2) R\&D cooperation with outside companies in small and medium companies will improve the labor productivity performance of the company; 
(3) R\&D cooperation with outside companies in large companies will improve the revenue performance of the company;

(4) R\&D cooperation with outside companies in large companies will improve the labor productivity performance of the company.

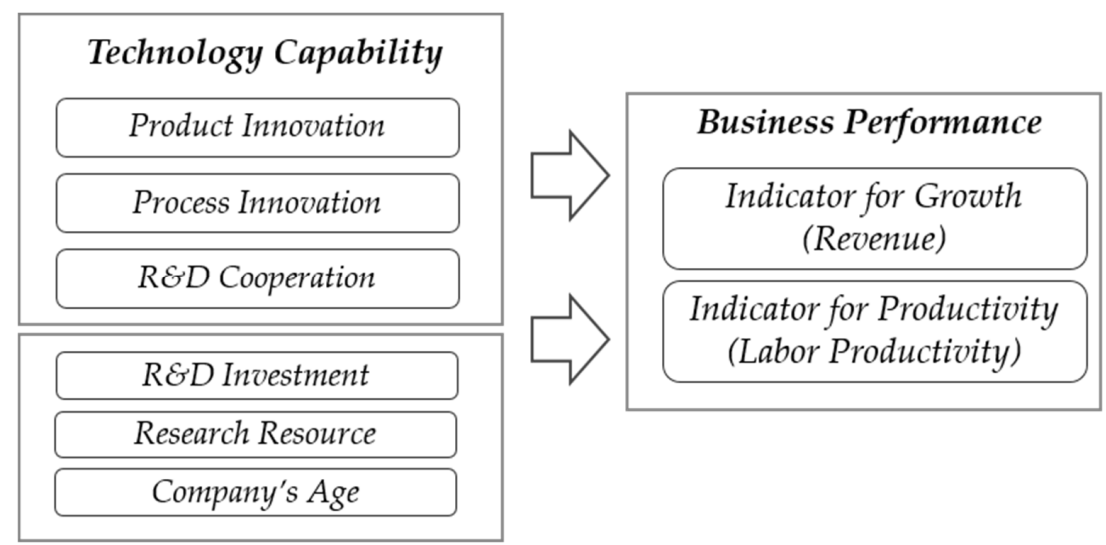

Figure 1. Research model.

\section{Methods}

\subsection{Data Collection}

The main objective of this study was to determine, based on panel regression analysis, whether technological innovation activities (including product innovation, process innovation, and R\&D cooperation) significantly influence the business performance of SMEs and large companies.

This study utilized technological innovation and performance data for Korean companies published by STEPI and financial statistical data from the Financial Supervisory Service; these data were analyzed using the statistical programs $\mathrm{R}$ and Stata 14.2. The sample consisted of 80 large companies with more than 1000 employees or subsidiaries of a large group and 80 SMEs with fewer than 250 employees from the Korean IT and business service industry. The study period was 2009-2017 and the description of companies and the survey used in our research are described in Tables 1 and 2, and the variables used in our research are presented in Tables 3-5 provide the descriptive statistics of the variables and the correlations between them. It can be observed that there were no multi-collinearity problems among the independent variables.

Table 1. Description of companies (small- and medium-sized enterprises (SMEs) and large companies).

\begin{tabular}{ccccc}
\hline \multicolumn{2}{c}{ Category } & SMEs & Large Companies & Total (Average) \\
\hline \multicolumn{2}{c}{ Observation (No.) } & 80 & 80 & 160 \\
\hline \multirow{3}{*}{ Industry Type } & Telecommunication & $9(11 \%)$ & $12(15 \%)$ & $21(13 \%)$ \\
& System Integration & $41(51 \%)$ & $24(30 \%)$ & $65(41 \%)$ \\
& Information & $13(16 \%)$ & $25(31 \%)$ & $38(24 \%)$ \\
& Technology & $17(21 \%)$ & $19(24 \%)$ & $36(23 \%)$ \\
\hline \multirow{2}{*}{ Area } & Capital Region & $61(76 \%)$ & $75(95 \%)$ & $146(85 \%)$ \\
& Non-Capital & $19(24 \%)$ & $5(5 \%)$ & $24(15 \%)$ \\
\hline \multicolumn{2}{c}{ Cogion } & 19 & 31 & $(25)$ \\
\hline \multicolumn{2}{c}{ Company Age (years) } & $24 \mathrm{M}$ & $734 \mathrm{M}$ & $(379)$ \\
\hline
\end{tabular}

Source: Science and Technology Policy Institute, Korea Information Technology Service Industry Association. 
Table 2. Information for survey.

\begin{tabular}{|c|c|c|c|c|c|c|c|c|}
\hline \multicolumn{2}{|c|}{ Category } & \multicolumn{7}{|c|}{ Description } \\
\hline General firm cha & eristics & \multicolumn{7}{|c|}{ Firm basics, R\&D, management, comparisons } \\
\hline Innovation & & \multicolumn{7}{|c|}{$\begin{array}{c}\text { Innovation (activity) rates, R\&D activity rates, ongoing and abandoned } \\
\text { innovation, comparison }\end{array}$} \\
\hline Innovation ou & nes & \multicolumn{7}{|c|}{$\begin{array}{l}\text { Service product innovation, process innovation, organization innovation } \\
\text { marketing innovation }\end{array}$} \\
\hline Actors and level o & ovation & \multicolumn{7}{|c|}{ Actors of innovation, level of innovation } \\
\hline Innovation activiti & nd costs & \multicolumn{7}{|c|}{ Innovation activities, innovation activities by type, innovation costs } \\
\hline $\begin{array}{r}\text { Information sol } \\
\text { cooperati }\end{array}$ & and & \multicolumn{7}{|c|}{ Information sources, innovation cooperation, user innovation } \\
\hline $\begin{array}{l}\text { Objectives and i } \\
\text { innovati }\end{array}$ & ts of & \multicolumn{7}{|c|}{ Objectives of innovation, impacts of innovation } \\
\hline Appropriability of & iovation & \multicolumn{7}{|c|}{$\begin{array}{l}\text { Utilization of methods of protection, importance of methods of } \\
\text { protection }\end{array}$} \\
\hline Obstacles of in & ation & \multicolumn{7}{|c|}{$\begin{array}{l}\text { Relevancies of obstacles of innovation, importance of obstacles of } \\
\text { innovation }\end{array}$} \\
\hline $\begin{array}{r}\text { Government supp } \\
\text { procurem }\end{array}$ & patents, & \multicolumn{7}{|c|}{$\begin{array}{l}\text { Utilization of government support, importance of government support } \\
\text { patents, public procurements }\end{array}$} \\
\hline \multicolumn{9}{|c|}{ Source: Science and Technology Policy Institute (The Korean Innovation Survey: Service, Manufacturing). } \\
\hline \multicolumn{2}{|c|}{ Variables } & & \multicolumn{6}{|c|}{ Definition } \\
\hline \multicolumn{9}{|c|}{ Dependent Variable: Business Performance } \\
\hline \multicolumn{3}{|c|}{$\begin{array}{l}\text { Indicator for growth (GR) } \\
\text { Indicator for productivity (PR) }\end{array}$} & Profit & wth rat & $\begin{array}{l}\text { wth rate } \\
\text { ivided } b\end{array}$ & $\begin{array}{l}\text { sales } \\
\text { umber }\end{array}$ & mployee & \\
\hline \multicolumn{9}{|c|}{ Independent Variable: Technological Innovation } \\
\hline \multicolumn{3}{|c|}{$\begin{array}{l}\text { Product innovation (PDC) } \\
\text { Process innovation (PCC) }\end{array}$} & \multicolumn{6}{|c|}{$\begin{array}{c}\text { Number of new products or re-engineered products } \\
\text { Number of new processes or re-engineered processes } \\
\text { Number of external entities engaged in cooperative } \\
\text { R\&D }\end{array}$} \\
\hline \multicolumn{9}{|c|}{ Control Variables: } \\
\hline \multicolumn{3}{|c|}{$\begin{array}{l}\text { R\&D investment }(\mathrm{RI}) \\
\text { Research resource }(\mathrm{RR}) \\
\text { Company age }(\mathrm{CA})\end{array}$} & Cur & $\begin{array}{l}\mathrm{Ir} \\
\text { ber of } \mathrm{d} \\
\text { year }(2\end{array}$ & $\begin{array}{l}\text { stment } \\
\text { icated re } \\
\text { ) versus }\end{array}$ & $\begin{array}{l}\text { R\&D } \\
\text { rces fo } \\
\text { ar of es }\end{array}$ & $\begin{array}{l}\text { search } \\
\text { lishment }\end{array}$ & \\
\hline \multicolumn{9}{|c|}{$\begin{array}{l}\text { Data Set: 2009-2017. Source: Science and Technology Policy Institute, Data were collected through surveys on 1:1 } \\
\text { interview by paying visits to companies in Korea in order to understand and evaluate the technological innovation } \\
\text { status of the companies, Korea Information Technology Service Industry Association, Financial data (Financial } \\
\text { Supervisory Service of Korea). }\end{array}$} \\
\hline Characteristic & GR & PR & PDC & PCC & RDC & RI & $\mathbf{R R}$ & CA \\
\hline Min. Value & 5.2 & 1.23 & 7.28 & 6.34 & 0.00 & 0.21 & 0.00 & 2.00 \\
\hline Max. Value & 62.3 & 3.80 & 17.38 & 15.66 & 7.00 & 2.56 & 15.00 & 32.00 \\
\hline Average & 23.9 & 1.82 & 11.32 & 10.26 & 4.32 & 1.22 & 8.23 & 19.00 \\
\hline Standard Deviation & 8.7 & 0.78 & 2.23 & 2.15 & 1.21 & 0.77 & 0.99 & 0.22 \\
\hline Skewness & 0.66 & 2.12 & 0.22 & 1.24 & 0.67 & 1.23 & 1.07 & 1.66 \\
\hline Kurtosis & -0.81 & 2.52 & 0.54 & 0.88 & -1.35 & 0.33 & -0.20 & 1.91 \\
\hline Observation & 800 & 800 & 800 & 800 & 800 & 800 & 800 & 800 \\
\hline
\end{tabular}


Table 4. Cont.

\begin{tabular}{ccccccccc}
\hline Characteristic & GR & PR & PDC & PCC & RDC & RI & RR & CA \\
\hline GR & 1 & & & & & & & \\
PR & $0.328^{* *}$ & 1 & & & & & & \\
PDC & $0.149^{* * *}$ & $0.232^{* *}$ & 1 & & & & & \\
PCC & $0.204^{* *}$ & $0.378^{*}$ & $0.241^{* *}$ & 1 & & & & \\
RDC & $0.246^{* * *}$ & $0.254^{*}$ & $0.427^{* * *}$ & $0.410^{* *}$ & 1 & & & \\
RI & $0.534^{* *}$ & $0.409^{* *}$ & $0.373^{* *}$ & $0.578^{* *}$ & $0.179 *$ & 1 & & \\
RR & $0.444^{*}$ & $0.338^{*}$ & $0.412^{*}$ & $0.362^{*}$ & $0.154^{*}$ & $0.465^{* *}$ & 1 \\
CA & $0.496^{* *}$ & $0.214^{* *}$ & $0.124^{* *}$ & $0.391^{* *}$ & $0.302^{*}$ & $0.338^{*}$ & $0.323^{* *}$ & 1 \\
\hline
\end{tabular}

Note: GR: Indicator for growth, PR: Indicator for productivity, PDC: Product competitive, PCC: Process competitive, RDC: R\&D cooperation, RI: R\&D investment, RR: Research resource, CA: Company age. ${ }^{* * *}, * *, *$ represent the significance at the level of $1 \%, 5 \%, 10 \%$, respectively.

Table 5. Data set summary for large companies.

\begin{tabular}{ccccccccc}
\hline Characteristic & GR & PR & PDC & PCC & RDC & RI & RR & CA \\
\hline Min. Value & 314.28 & 6.11 & 28.32 & 12.34 & 0.00 & 13.22 & 48.00 & 11.00 \\
Max. Value & 1046.2 & 18.56 & 52.38 & 49.66 & 52.00 & 65.34 & 250.00 & 65.00 \\
Average & 742.52 & 11.33 & 38.64 & 31.65 & 21.32 & 39.22 & 178.23 & 31.00 \\
Standard Deviation & 95.66 & 2.56 & 3.23 & 4.15 & 3.21 & 6.32 & 10.22 & 5.21 \\
Skewness & 0.25 & 0.13 & 0.73 & 2.13 & 1.67 & 0.12 & 1.33 & 1.57 \\
Kurtosis & 1.15 & 1.24 & -1.46 & 2.55 & 0.81 & -1.99 & 0.21 & 0.48 \\
Observation & 800 & 800 & 800 & 800 & 800 & 800 & 800 & 800 \\
\hline Characteristic & GR & PR & PDC & PCC & RDC & RI & RR & CA \\
\hline GR & 1 & & & & & & & \\
PR & $0.113^{* *}$ & 1 & & & & & & \\
PDC & $0.203^{* * *}$ & $0.269^{* *}$ & 1 & & & & & \\
PCC & $0.395^{* *}$ & $0.218^{*}$ & $0.181^{* *}$ & 1 & & & & \\
RDC & $0.354^{* *}$ & $0.346^{* *}$ & 0.292 & $0.179 *$ & 1 & & & \\
RI & $0.561^{* *}$ & 0.229 & $0.268^{* *}$ & $0.117^{*}$ & $0.492^{* *}$ & 1 & & \\
RR & $0.173^{* *}$ & $0.176^{*}$ & $0.133^{*}$ & $0.083 *$ & $0.402^{* *}$ & $0.256^{* *}$ & 1 \\
CA & $0.232^{*}$ & $0.209^{* *}$ & $0.429^{*}$ & 0.137 & $0.459 *$ & $0.325^{*}$ & $0.160 * *$ \\
\hline
\end{tabular}

Note: GR: Indicator for growth, PR: Indicator for productivity, PDC: Product competitive, PCC: Process competitive, RDC: R\&D cooperation, RI: R\&D investment, RR: Research resource, CA: Company age. ${ }^{* * *}, * *,{ }^{*}$ represent the significance at the level of $1 \%, 5 \%, 10 \%$ respectively.

\subsection{Econometric Methodology}

Using panel regression analysis, our study investigated the influence of technological innovation activity on business performance. In this context, the following two models were estimated:

Large companies: $Y_{i t+2}=\alpha+\sum_{k=1}^{k} \beta_{k i t} X_{K}+u_{i t,}\left(\mu_{i t}=\mu_{i}+\varepsilon_{i t}\right)$;

SMEs: $Y_{i t+2}=\alpha+\sum_{k=1}^{k} \beta_{k i t} X_{K}+u_{i t,}\left(\mu_{i t}=\mu_{i}+\varepsilon_{i t}\right)$

Model 1: Revenue as a dependent variable;

$\ln G R_{j, t+2}=\beta_{1} \ln P D C_{j, t}+\beta_{2} \ln P C C_{j, t}+\beta_{3} \ln R D C_{j, t}+\beta_{4} \ln R I_{j, t}+\beta_{5} \ln R R_{j, t}+\beta_{6} \ln C A_{j, t}+\varepsilon_{j, t} ;$

Model 2: Labor productivity as a dependent variable;

$\ln P R_{j, t+2}=\beta_{1} \ln P D C_{j, t}+\beta_{2} \ln P C C_{j, t}+\beta_{3} \ln R D C_{j, t}+\beta_{4} \ln R I_{j, t}+\beta_{5} \ln R R_{j, t}+\beta_{6} \ln C A_{j, t}+\varepsilon_{j, t}$.

Our study first developed a panel linear regression model with a two-year lag between the dependent and independent variables using cross-sectional panel data for the 160 target companies and data from 2009 to 2017. A lag of two years was selected because this is the average time between the application of technological innovation and the generation of profit [52]. It should be noted, however, that the time it takes for the benefits of technological innovation to be realized will depend on the size, characteristics, and timing of the innovation, as well as the country, industry, and technology 
field [53]. Our study comprehensively analyzed the factors affecting sales and labor productivity by distinguishing between large companies and SMEs. First, the existence of cross-sectional dependence among the cross-sectional units was examined using Pesaran et al.'s 『L】_(adj.) test [54], followed by panel regression analysis using Chow $(F)$ and BP ( $\left.x^{\wedge} 2\right)$ tests for random and fixed effects estimation [55]. In particular, because the factors impacting corporate technological innovation capabilities are very diverse, it is almost impossible to analyze every such element individually. Therefore, it is necessary to accept that there are likely to be important variables that are not observed in the model, no matter how many explanatory variables are added to the analysis model [56]. Accordingly, it was determined that it would be possible to conceptually understand important underlying mechanisms by investigating a selection of important variables and accounting for the unobserved variables. Therefore, the panel data analysis used in our study provided optimal model results by appropriately handling these unobserved missing variables [54,55]. In addition, various analysis techniques can be employed on panel data, which is useful for deriving policy implications [56]. Using this approach, we were able to investigate technological innovation factors that significantly affect the performance of large companies and SMEs.

\section{Results}

Panel analysis should take into account the characteristics of the object fixed with the error term a, so the test of whether the error term a is significant should precede the analysis [52]. Accordingly, our study analyzed the suitability of panel analysis through the Lagrangian Multiplier test of Breusch-Pagan (1980) and modified Wald bivariance test before empirical analysis [52]. The Lagrangian Multiplier test of Breusch-Pagan (1980) and modified Wald bivariance test is an analysis to determine whether panel analysis is more valid than the pooled ordinary least squares (OLS). If the null hypothesis $H_{0}: \sigma_{\alpha}^{2}=\sigma_{n}^{2}=0, H_{0}: \operatorname{var}\left(n_{i t}\right)=\sigma^{2}$ is rejected, the residual means to have a binary that can cause the endogenesis problem. Therefore, the results of the pooled OLS are unreliable, and in this case panel analysis was more appropriate. Table 6 shows the results of the Lagrangian Multiplier test of Breusch-Pagan (1980) and modified Wald bivariance test, and it was confirmed that all of them were significant at the $1 \%$ level, so panel analysis was more valid than pooled OLS.

Table 6. Breusch-Pagan Lagrange Multiplier (LM) test result.

\begin{tabular}{ccccc}
\hline \multirow{2}{*}{ Variable } & \multicolumn{2}{c}{ Small and Medium } & \multicolumn{2}{c}{ Large } \\
\cline { 2 - 4 } & GR & PR & GR & PR \\
\hline Breusch-Pagan LM test & $318.22^{* * *}$ & $278.14^{* * *}$ & $189.88^{* * *}$ & $269.44^{* * *}$ \\
\hline Modified Wald test for heteroskedasticity & $4.4 \mathrm{e}+52^{* * *}$ & $7.8 \mathrm{e}+32^{* * *}$ & $2.4 \mathrm{e}+18^{* * *}$ & $3.2 \mathrm{e}+17^{* * *}$ \\
\hline \multicolumn{4}{c}{${ }^{* * *}$ represent the significance at the level of $1 \%}$. \\
\end{tabular}

Our study was conducted using the most widely used fixed effect model and random effect model in panel analysis. The fixed effect model considers the error term $\alpha \_i$ as a parameter to be estimated, not a random variable, and assumes that it is fixed while being different from each other by panel object. That is, $B$ which is a tilt parameter, is the same as each other for all panel objects, but $\alpha \_i$ is different for each panel object [56]. On the other hand, the random effect model assumes an error term $\alpha \_i$ as a random variable. The fixed effect model and the random effect model for panel analysis vary depending on which model you select. If $\operatorname{cov}\left(x_{i t}, \alpha_{i}\right)=0$, the estimates of the fixed effect and the random effect are both consistent estimators, so they have similar results. However, if $\operatorname{cov}\left(x_{i t}, \alpha_{i}\right) \neq 0$, there is a systematic difference in the estimation result when the estimator of the random effect model does not become a match estimator. The Hausman test can test the selection of a fixed effect model and a random effect model based on this assumption [56].

The fixed-effects model was used to analyze the effects of product innovation, process innovation, and R\&D cooperation on the performance of the companies (Table 7). For Model 1, in which revenue was a dependent variable, the results for SMEs revealed that process innovation did not have a significant 
effect on revenue. However, product innovation and R\&D cooperation were found to positively affect revenue, as did the control variables, R\&D investment, research resources, and company age. Also, in Model 2, in which labor productivity was a dependent variable, process innovation did not have a significant effect on productivity, while product innovation and R\&D cooperation were found to positively affect productivity, as did R\&D investment, research resources, and company age. For large companies, Model 1 revealed that R\&D cooperation did not have a significant effect on revenue, but both forms of innovation and the three control variables did. The productivity results from Model 2 for large companies were the same as for Model 1, except company age as the control variable did not have a significant effect on productivity.

Table 7. Panel regression results for revenue (model 1) and productivity (model 2).

\begin{tabular}{ccccc}
\hline \multirow{2}{*}{ Characteristic } & \multicolumn{2}{c}{ SMEs } & \multicolumn{2}{c}{ Large Companies } \\
\cline { 2 - 5 } & Model 1 (GR) & Model 2 (PR) & Model 1 (GR) & Model 2 (PR) \\
\hline \multirow{2}{*}{ Product innovation (PDC) } & $0.505^{* * *}$ & $0.320^{* * *}$ & $0.136^{* *}$ & $0.167^{* * *}$ \\
& $(0.155)$ & $(0.113)$ & $(0.042)$ & $(0.045)$ \\
\hline \multirow{2}{*}{ Process innovation (PCC) } & 0.170 & 0.493 & $0.091^{* * *}$ & $0.176^{* * *}$ \\
& $(0.246)$ & $(0.082)$ & $(0.046)$ & $(0.051)$ \\
\hline \multirow{2}{*}{ R\&D cooperation (RDC) } & $0.204^{* * *}$ & $0.439^{* * *}$ & 0.284 & 0.260 \\
& $(0.091)$ & $(0.082)$ & $(0.135)$ & $(0.037)$ \\
\hline \multirow{2}{*}{ R\&D investment (RI) } & $0.229^{* * *}$ & $0.351^{* * *}$ & $0.304^{* * *}$ & $0.140^{* * *}$ \\
Research resources (RR) & $(0.013)$ & $(0.172)$ & $(0.032)$ & $(0.036)$ \\
\hline Company age (CA) & $1.210^{* *}$ & $0.341^{* *}$ & $0.336^{* * *}$ & $0.140^{* * *}$ \\
& $(0.562)$ & $(0.102)$ & $(0.045)$ & $(0.036)$ \\
\hline Constant & $0.046^{* * *}$ & $0.028^{* * *}$ & $0.013^{* *}$ & 0.008 \\
Within & $(0.004)$ & $(0.002)$ & $(0.008)$ & $(0.008)$ \\
\hline Between & $6.282^{* * *}$ & $2.551^{* * *}$ & $9.95^{* * *}$ & $5.62^{* * *}$ \\
R2 Overall & 0.247 & 0.228 & 0.383 & 0.362 \\
f-value (Wald Chi2) & 0.127 & 0.180 & 0.254 & 0.222 \\
Hausman test & 0.181 & 0.161 & 0.283 & 0.245 \\
Companies & 48.70 & 43.96 & 18.84 & 7.61 \\
\hline
\end{tabular}

Note: Standard errors are reported in brackets. GR = growth in revenue, $\mathrm{PR}=$ productivity rate. ${ }^{* * *},{ }^{* *}$, represent the significance at the level of $1 \%, 5 \%$ respectively.

\section{Discussion}

The results of our study discovered that technological innovation significantly contributes to increasing sustainable business performance. Technological innovation factors, product innovation, process innovation, and R\&D cooperation have an important effect on sustainable business performance in both SMEs and large companies of Korea. These results are consistent with the literature. All these factors have a significant interrelation with products and services, and these enhance the performance of the companies [12]. It has been proven by various previous studies that technological innovation has a positive effect on revenue growth and product performance, which improves the business performance $[10,30]$. As described by the literature, technological innovation implementation and business performance have a significant relationship with each other [36,41,45]. It was mentioned that advancements in technological innovation can greatly change organizational performance, such as increase sales performance, transform the business model, and stimulate innovation in other areas [12]. Technological innovation plays an important role in various areas of sustainable development: social, environmental, and economic [11]. So, better enhancement of technological innovation in the firms has a significant role in improving sustainable business performance in all aspects. 
The hypotheses verified by the analysis of the effects of corporate technological innovation activity on corporate performance are presented in Table 8 . Product innovation, which companies develop to maintain their existing market and expand into new markets, was found to improve sales performance and productivity in both SMEs and large companies. It was also found that process innovation via the improvement of current processes and the introduction of new processes contributed to significantly higher sales performance and labor productivity in large companies, but SMEs experienced no significant effect. When implementing process innovation, large companies with relatively high market accessibility and recognition can take advantage of internal and external systems that SMEs do not have access to. In addition to that, large companies have the advantage of large-scale investment and infrastructure for new product creation and the improvement of existing products; they can implement technological innovations that are highly effective in reducing internal production costs and proving productivity, while SMEs, with less infrastructure, do not experience the same benefits. The positive influence of external R\&D cooperation on business performance was demonstrated to be statistically significant for SMEs but not for large companies. From a strategic perspective, SMEs are likely to engage in various $R \& D$ cooperation activities to acquire knowledge, such as technical alliances, the imitation of fair-use technology [44]. On the other hand, large companies will be more reluctant to engage in cooperation with outside organizations to prevent the leakage of technology. In addition, successful large companies typically already have sufficient internal R\&D capabilities [46]. Thus, large companies typically employ more researchers for their own R\&D activity than SMEs. However, cooperative R\&D has a positive effect on both the revenue and labor productivity of SMEs. A number of studies explained that the external R\&D cooperation can slow the internal process when the internal process is complex. The reasons for this are that it is difficult to integrate the external knowledge of other organizations and to adapt to different standards and language codes and that implicit or complex technologies act as an obstacle to innovation during the process of technology transfer through technical cooperation [11]. Therefore, large companies tend to have relatively complex internal processes, and they will therfore prefer to avoid R\&D cooperation with outside organizations.

Table 8. Results for hypothesis testing.

\begin{tabular}{|c|c|}
\hline \multicolumn{2}{|l|}{ Hypothesis } \\
\hline $\begin{array}{l}\mathrm{H} 1 \text {. } \\
\begin{array}{l}\text { Technological innovation activities for product innovation will improve the } \\
\text { performance of the company. }\end{array}\end{array}$ & Accepted \\
\hline $\begin{array}{l}\text { (1) Technological innovation activities for product innovation in small and medium } \\
\text { companies will improve the revenue performance of the company. }\end{array}$ & Accepted \\
\hline $\begin{array}{l}\text { (2) Technological innovation activities for product innovation in small and medium } \\
\text { companies will improve the labor productivity performance of the company. }\end{array}$ & Accepted \\
\hline $\begin{array}{l}\text { (3) Technological innovation activities for product innovation in large companies } \\
\text { will improve the revenue performance of the company. }\end{array}$ & Accepted \\
\hline $\begin{array}{l}\text { (4) Technological innovation activities for product innovation in large companies } \\
\text { will improve the labor productivity performance of the company. }\end{array}$ & Accepted \\
\hline $\begin{array}{l}\mathrm{H} 2 \text {. } \\
\begin{array}{l}\text { Technological innovation activities for process innovation will improve the } \\
\text { performance of the company. }\end{array}\end{array}$ & Partially Accepted \\
\hline $\begin{array}{l}\text { (1) Technological innovation activities for process innovation in small and medium } \\
\text { companies will improve the revenue performance of the company. }\end{array}$ & Not Accepted \\
\hline $\begin{array}{l}\text { (2) Technological innovation activities for process innovation in small and medium } \\
\text { companies will improve the labor productivity performance of the company. }\end{array}$ & NotAccepted \\
\hline $\begin{array}{l}\text { (3) Technological innovation activities for process innovation in large companies } \\
\text { will improve the revenue performance of the company. }\end{array}$ & Accepted \\
\hline
\end{tabular}


Table 8. Cont.

\begin{tabular}{cc}
\hline & Hypothesis \\
\hline $\begin{array}{c}\text { (4) Technological innovation activities for process innovation in large companies } \\
\text { will improve the labor productivity performance of the company. }\end{array}$ & Accepted \\
\hline $\begin{array}{c}\text { H3. } \\
\text { R\&D cooperation with outside companies will improve the performance of } \\
\text { companies. }\end{array}$ & Partially Accepted \\
\hline $\begin{array}{c}\text { (1) R\&D cooperation with outside companies in small and medium companies will } \\
\text { improve the revenue performance of the company. }\end{array}$ & Accepted \\
\hline $\begin{array}{c}\text { (2) R\&D cooperation with outside companies in small and medium companies will } \\
\text { improve the labor productivity performance of the company. }\end{array}$ & Accepted \\
\hline $\begin{array}{c}\text { (3) R\&D cooperation with outside companies in large companies will improve the } \\
\text { revenue performance of the company. }\end{array}$ & Not Accepted \\
\hline labor productivity performance of the company. & Not Accepted \\
\hline
\end{tabular}

\section{Conclusions}

Recently, companies have needed to demonstrate an active response to external changes, such as the emergence of the fourth industrial revolution, low economic growth, and sustainable development. To achieve this, companies are required to devise strategies to secure a sustainable competitive advantage through innovative internalization and to improve their corporate capabilities and their sustainable development in all of its aspects: social, environmental, and economic. In this process, the role of companies as participants in innovation and their willingness to create, spread, and engage in innovation activity have been emphasized in the technological innovation field. Indeed, the technological innovation strategies, structural competitiveness, and expanded internal capabilities of companies can be the foundation for the competitiveness of a nation as a whole and sustainable development. Our study looked at innovation activity as a new growth engine for companies and focused on the effects of this activity on corporate performance in terms of growth and productivity.

Our research established a systematic empirical analysis model and analyzed the differential impact of corporate innovation on large companies and SMEs according to the innovation type (i.e., product and process innovation and R\&D cooperation). The analysis found that there were some similarities in the results of the empirical analysis for large companies and SMEs, but there were also considerable differences. The technology level and accumulated knowledge capacity of companies are very important in pursuing innovation, with large companies generally more effective in improving revenue and productivity through technological innovation. Similarly, a limited innovation capacity and a lack of knowledge-creating mechanisms have a negative effect on innovation performance. The results for the independent variables can be summarized as follows. First, product and process innovation had significant effects on business performance for large companies, while R\&D cooperation did not affect the business performance of large companies. Second, product innovation and $R \& D$ cooperation had a statistically significant positive effect on both revenue and productivity for SMEs, while process innovation did not affect the business performance of SMEs. Based on these results, it is necessary to establish governmental policies that consider the innovation type and its impact on outcomes for SMEs in particular, rather than issuing uniform policy prescriptions.

Indeed, the government's active and strategic support of technological innovation in SMEs can have a significant impact on long-term technological performance and productivity. In addition, in order to strengthen corporate innovation capacity, an innovative and friendly policy environment that can promote competition and innovation and increase government-led R\&D investment should simultaneously be established.

Despite the contributions of the present study, it has the following limitations. Corporate innovation performance was analyzed based on revenue and productivity only, but there are 
many variables can reflect corporate sustainability and innovation performance. To analyze the unique influence of each technological innovation, there is much to implement to more thoroughly conceptualize, and as a result, empirically explore this aspect. Similarly, our study used only two dimensions to measure a firm's performance. Other areas (non-financial performance, customer performance) should be considered in future research to explain the results in a better way. Therefore, further research is needed to develop multi-dimensional measurement indicators that can accommodate a wide range of technological innovation measures.

Author Contributions: S.H.J. did Conceptualization, Data curation, Formal analysis, Investigation, Methodology, Visualization, Writing- original draft preparation. S.O.C did Writing - review \& editing, Supervision, Validation.

Funding: This research received no external funding.

Acknowledgments: The special thanks to Society of Open Innovation: Technology, Market, and Complexity (SOItmC) and JinHyo Joseph Yun, the president of SOItmC, to support our research.

Conflicts of Interest: The authors declare no conflict of interest.

\section{References}

1. Schumpeter, J.A. The Theory of Economic Development; Harvard University Press: Cambridge, MA, USA, 1934.

2. Dodgson, M.; Gann, D.; Salter, A. The role of technology in the shift towards open innovation: The case of Procter and Gamble. R D Manag. 2006, 36, 333-346. [CrossRef]

3. Chesbrough, H.W. Open Innovation: The New Imperative for Creating and Profiting from Technology; Harvard Business School Press: Boston, MA, USA, 2003.

4. Schreier, M.; Prugl, R. Extending Lead-User Theory: Antecedents and Consequences of Consumers' Lead Userness. J. Prod. Innov. Manag. 2008, 25, 341-346. [CrossRef]

5. Lettl, C.; Herstatt, C. Users' contributions to radical innovation: Evidence from four cases in the field of medical equipment technology. $R$ D Manag. 2006, 36, 251-272. [CrossRef]

6. Amara, N.; Landry, R. Sources of information as determinants of novelty of innovation in manufacturing firms: Evidence from the 1999 statistics Canada in novation survey. Technovation 2005, 24, 245-259.

7. Laursen, K.; Salter, A. Open for innovation: The role of openness in explaining innovation performance among U. K. manufacturing firms. Strateg. Manag. J. 2006, 27, 131-150. [CrossRef]

8. Faems, D.; Van Looy, B.; Debackere, K. Interorganizational collaboration and innovation: Toward a portfolio approach. J. Prod. Innov. Manag. 2005, 22, 238-250.

9. Kim, D.G.; Choi, S.O. Impact of Construction IT Technology Convergence Innovation on Business Performance. Sustainability 2018, 10, 3972. [CrossRef]

10. Zhang, Y.; Khan, U.; Lee, S.; Salik, M. The Influence of Management Innovation and Technological Innovation on Organization Performance. A Mediating Role of Sustainability. Sustainability 2019, 11, 495.

11. Pinto, M.M.A.; Kovaleski, J.L.; Yoshino, R.T.; Pagani, R.N. Knowledge and Technology Transfer Influencing the Process of Innovation in Green Supply Chain Management: A Multicriteria Model Based on the DEMATEL Method. Sustainability 2019, 11, 3485.

12. Yam, R.C.M.; Lo, W.; Tang, E.P.Y.; Lau, K.W. Technological innovation capabilities and firm performance. World Acad. Sci. Eng. Technol. 2010, 42, 1009-1017.

13. Aunger, R. Types of technology. Technol. Forecast. Soc. Chang. 2010, 77, 762-782. [CrossRef]

14. Koc, T.; Ceylan, C. Factors impacting the innovative capacity in large-scale companies. Technovation 2007, 27, 105-114. [CrossRef]

15. Rogers, M. The Definition and Measurement of Innovation; Melbourne Institute of Applied Economic and SocialResearch: Melbourne, Australia, 1998; No.10/98.

16. Cohen, W.M.; Levinthal, D.A. Absorptive capacity: A new perspective on learning and innovation. Adm. Sci. Q. 1990, 35, 128-152. [CrossRef]

17. Utterback, J.M.; Abernathy, W.J. A dynamic model of process and product innovation. Omega 1975, 3, 639-656.

18. Van de Ven, A.H. Central problems in the management of innovation. Manag. Sci. 1986, 32, 590-607. 
19. Yun, J.J.; Jeong, E.; Lee, Y.; Kim, K. The effect of open innovation on technology value and technology transfer: A comparative analysis of the automotive, robotics, and aviation industries of Korea. Sustainability 2018, 10, 2459. [CrossRef]

20. Hertog, P.D. Knowledge-intensive business services as co-producers of innovation. Int. J. Innov. Manag. 2000, 4, 491-528.

21. Anwar, M. Business model innovation and SMES performance-Does competitive advantage mediate? Int. J. Innov. Manag. 2018, 22, 1850057. [CrossRef]

22. Santarelli, E.; Vivarelli, M. Entrepreneurship and the process of firms' entry, survival and growth. Ind. Corp. Chang. 2007, 16, 455-488.

23. Coccia, M. Sources of technological innovation: Radical and incremental innovation problem-driven to support competitive advantage of firms. Technol. Anal. Strateg. Manag. 2017, 29, 1048-1061. [CrossRef]

24. Camisón, C.; Villar-López, A. Organizational innovation as an enabler of technological innovation capabilities and firm performance. J. Bus. Res. 2014, 67, 2891-2902. [CrossRef]

25. Chae, H.C.; Koh, C.E.; Park, K.O. Information technology capability and firm performance: Role of industry. Inf. Manag. 2018, 55, 525-546.

26. Li, Y.; Zhao, Y.; Liu, Y. The relationship between HRM, technology innovation and performance in China. Int. J. Manpow. 2006, 27, 679-697.

27. Miller, D.J.; Fern, M.J.; Cardinal, L.B. The use of knowledge for technological innovation within diversified firms. Acad. Manag. J. 2007, 50, 307-325. [CrossRef]

28. Sirilli, G.; Evangelista, R. Technological innovation in services and manufacturing: Results from Italian surveys. Res. Policy 1998, 27, 881-899. [CrossRef]

29. Hervas-Oliver, J.L.; Sempere-Ripoll, F.; Boronat-Moll, C.; Rojas-Alvarado, R. On the joint effect oftechnological and management innovations on performance: Increasing or diminishing returns? Technol. Anal. Strateg. Manag. 2018, 30, 569-581. [CrossRef]

30. Haseeb, M.; Hussain, H.I.; Ślusarczyk, B.; Jermsittiparsert, K. Industry 4.0: A solution towards technology challenges of sustainable business performance. Soc. Sci. 2019, 8, 154. [CrossRef]

31. Faller, C.; Feldmüller, D. Industry 4.0 Learning Factory for regional SMEs. Procedia CIRP 2015, 32, 88-91. [CrossRef]

32. Vrchota, J.; Volek, T.; Novotná, M. Factors Introducing Industry 4.0 to SMES. Soc. Sci. 2019, 8, 130. [CrossRef]

33. Ganzarain, J.; Errasti, N. Three Stage Maturity Model in SME's towards Industry 4.0. J. Ind. Eng. Manag. 2016, 95, 1119-1128.

34. Teece, D.J. Firm Organization, Industrial Structure, and Technological Innovation. J. Econ. Behav. Organ. 1996, 31, 193-224.

35. Evangelista, R.; Perani, G.; Raptit, F.; Archibugi, D. Nature and Impact of Innovation in Manufacturing: Some Evidence from the Italian Innovation Survey. Res. Policy 1997, 26, 521-536.

36. Danneels, E. The Dynamic of Product Innovation and Firm Competences. Strat. Manag. J. 2002, 23, $1095-1121$. [CrossRef]

37. Galende, J.; Fuente, J.M. Internal Factors Determining a Firm's Innovative Behavior. Res. Policy 2003, 32, 715-736. [CrossRef]

38. Choi, J.Y.; Jeong, S.; Kim, K. A study of diffusion pattern of technology convergence: Patent analysis for Korea. Sustainability 2015, 7, 11546-11569. [CrossRef]

39. Mention, A.L.; Asikainen, A.L. Innovation \& productivity: Investigating effects of openness in services. Int. J. Innov. Manag. 2012, 16, 1240004.

40. Yun, J.J.; Won, D.; Park, K. Dynamics from open innovation to evolutionary change. J. Open Innov. Technol. Mark. Complex. 2016, 2, 7.

41. Tubbs, M. The relationship between R \& D and company performance. Res. Technol. Manag. 2007, 50, $23-30$.

42. Yun, J.J.; Yang, J.; Park, K. Open innovation to business model: New perspective to connect between technology and market. Sci. Technol. Soc. 2016, 21, 324-348. [CrossRef]

43. Niedrich, R.W.; Swain, S.D. The influence of pioneer status and experience order on consumer brand preference: A mediated-effects model. J. Acad. Mark. Sci. 2003, 31, 468-480. [CrossRef]

44. Coad, A.; Rao, R. Innovation and firm growth in high-tech sectors: A quantile regression approach: A quantile regression approach. Res. Policy 2008, 37, 633-648. 
45. Miotti, L.; Sachwald, F. Co-operative R \& D: Why and with whom? An integrated framework of analysis. Res. Policy 2003, 32, 1481-1499.

46. Becker, W.; Dietz, J. R \& D cooperation and innovation activities of firms-evidence for the German manufacturing industry. Res. Policy 2004, 33, 209-223.

47. Deeds, D.L.; Rothaermel, F.T. Honeymoons and liabilities: The relationship between age and performance in research and development alliances. J. Prod. Innov. Manag. 2003, 20, 468-484. [CrossRef]

48. Cooke, P. Complex spaces: Global innovation networks \& territorial innovation systems in information \& communication technologies. J. Open Innov. Technol. Mark. Complex. 2017, 3, 9.

49. Yun, J.J. How do we conquer the growth limits of capitalism? Schumpeterian Dynamics of Open Innovation. J. Open Innov. Technol. Mark. Complex. 2015, 1, 17. [CrossRef]

50. Yun, J.J.; Won, D.; Park, K.; Jeong, E.; Zhao, X. The role of a business model in market growth: The difference between the converted industry and the emerging industry. Technol. Forecast. Soc. Chang. 2019, 146, 534-562. [CrossRef]

51. Bogliacino, F.; Pianta, M. Innovation and employment: A reinvestigation using revised Pavitt classes. Res. Policy 2010, 39, 799-809. [CrossRef]

52. Ahuja, G.; Katila, R. Technological acquisition and the innovative performance of acquiring firms: A longitudinal study. Strat. Manag. J. 2001, 22, 197-220.

53. Schiuma, G. Arts catalyst of creative organizations for the fourth industrial revolution. J. Open Innov. Technol. Mark. Complex. 2017, 3, 20. [CrossRef]

54. Pesaran, M.H.; Ullah, A.; Yamagata, T. A Bias-Adjusted LM Test of Error Cross-Section Independence. Econom. J. 2008, 11, 105-127. [CrossRef]

55. Li, T. Econometric Analysis of Cross Section and Panel Data (Book). J. Econ. Lit. 2002, 40, 1239-1241.

56. Greene, W.H. The econometric approach to efficiency analysis. Meas. Product. Effic. Product. Growth 2008, 1, 92-250. 